\title{
PERSUASIVE AND EDUCATIVE ADVERTISING CONTENT OF QUICK RESPONSE CODE INDONESIAN STANDARD IN PANDEMIC ERA
}

\author{
Evelyn Kristanti ${ }^{1 *}$, Rustono Farady Marta ${ }^{1}$ \\ ${ }^{1}$ Universitas Bunda Mulia \\ *e-mail: kristantievelyn@gmail.com
}

\begin{abstract}
Abstrak
Sistem pembayaran digital semakin meningkat pesat terutama saat pandemi Corona Virus Disease (COVID19) masuk ke Indonesia. Meningkatnya kemajuan teknologi juga membuat masyarakat semakin terbiasa dengan kegiatan bertransaksi tanpa menggunakan uang tunai. Hal ini disebabkan uang tunai dianggap sebagai salah satu media penyebaran COVID-19 yang disentuh oleh banyak orang secara bergantian. Guna mendukung program Pemulihan Ekonomi Nasional, Bank Indonesia (BI) mengembangkan inovasi QRIS Tanpa Tatap Muka (TTM) yang memungkinkan pengguna untuk melakukan pembayaran tanpa tatap muka dengan merchant dimana relevan di masa pandemi COVID-19 ini. BI memposisikan produk di mata konsumen dengan menggunakan internet dan media sosial YouTube sebagai platform yang berperan penting dalam membingkai paradigma masyarakat terhadap suatu realitas, sehingga mempengaruhi sikap masyarakat. Permasalahan penelitian ini ditujukan untuk mengetahui dan menganalisis isi iklan yang berjudul "Praktis Pakai QRIS TTM" pada channel YouTube BI. Peneliti menggunakan Means-End Chain (MEC) Theory. Penelitian ini merupakan penelitian kualitatif deskriptif dengan metode analisis isi. Berdasarkan penelitian yang telah dilakukan dapat disimpulkan bahwa analisis isi iklan ini berfungsi ganda persuasif dan edukatif.
\end{abstract}

Kata kunci: Analisis Isi; Iklan; Pembayaran Digital; QRIS; COVID-19

\begin{abstract}
The digital payment system had increased rapidly, especially when Corona Virus Disease (COVID-19) entered Indonesia. Increasing technological advances have shifted people's preference towards cashless transaction activities. These days, money is known to have spread viruses such as COVID-19. In order to support the National Economic Recovery program, Bank Indonesia (BI) developed Contactless QRIS, which allows users to make contactless payments with merchants during the COVID-19 pandemic. BI positions its products in the eyes of consumers by using the internet and YouTube social media as a platform that plays a vital role in framing society's paradigm towards a reality, thus influencing people's attitudes. The research problem is aimed to know and analyze the content analysis of advertising "Using Contactless QRIS Practically" on the BI YouTube channel. This study aimed to analyze the content of BI advertising entitled "Using Contactless QRIS Practically." Researchers used Means-End Chain (MEC) Theory. This study used descriptive qualitative research with the content analysis method. The research has shown that based on content analysis, this advertising was persuasive and educative.
\end{abstract}

Keywords: Content Analysis; Advertising; Digital Payment; QRIS; COVID-19

This is an open access article under the $\underline{C C B Y-S A}$ license.

Copyright $\odot 2021$ by Author. Published by Universitas Pendidikan Ganesha.

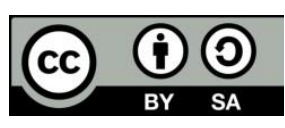

\section{INTRODUCTION}

Over the past two years, the digital payment system has increased rapidly, especially when Corona Virus Disease (COVID-19) entered Indonesia. Based on Bank Indonesia (BI) records, digital transactions increased by $37.8 \%$ per year. As of March 2021, the value of electronic money transactions has reached IDR 21.4 trillion or has been grown up to $42.46 \%$.
Different from previous research in 2019 , researchers found that Indonesia is still at the bulk transition stage where various digital payment instruments have emerged but their users are still limited (Aksami \& Jember, 2019). Increasing technological advances have shifted people preference towards cashless transaction activities (Saputri, 2020). These days, money is known to have spread viruses such as 
COVID-19 (Falah \& Puspaningrum, 2020). In other words, Large-Scale Social Restriction has accelerated the adoption of digital payment (Setiawan \& Mahyuni, 2020).

COVID-19 has spread around the world more than 1 year, including in Indonesia. COVID-19 is transmitted through the droplet route from the respiratory tract by direct contact (WHO, 2020). The response of countries around the world regarding this recent pandemic has also varied. Since the announcement of the first two cases of positive COVID-19 patients in Indonesia on March 2, 2020, the government has urged society to prevent and anticipate the spread of COVID-19 in Indonesia (Perbawa, 2021). Every citizen must play an active role in breaking the chain of the spread of COVID19 by applying physical distancing and wearing a mask (Apriyanti \& Widoyoko, 2021). Recorded until May 6, 2020, the number of COVID-19 cases has reached nearly 1.7 million people (Komite Penanganan COVID-19 Dan Pemulihan Ekonomi Nasional, 2021).

COVID-19 is very complex because it limits human social interactions (Angretnowati \& Anggraheni, 2021). Of course, this affects the social interactions that are usually carried out by requiring physical presence but utilizing technology to connect with one another. The COVID-19 pandemic has led to lifestyle changes in several sectors and provided new perspectives in various fields (Sari, 2021). One of them is payment. The habits that changed before the pandemic and during the pandemic created new reasons for using digital literacy. This concept includes the attitudes, interests and abilities of individuals in using digital technology and synergizing digital media in daily activities to increase productivity (Widyastuti, Nuswantoro, \& Sidhi, 2016).

In order to support the National Economic Recovery program, BI together with Payment System Service Providers are committed to encourage the expansion of the use of Quick Response Code Indonesian Standard or also known as QRIS. Looking back in 2020, there are 6 million merchants that have used QRIS so $\mathrm{BI}$ is targeting double to 12 million merchants using QRIS in 2021. In line with this commitment, BI is developing Contactless QRIS innovation that is relevant during COVID-19 pandemic in March 2020 (Indonesia, 2021a).
If previously we imagined that all of digital wallet applications could be combined into one code that was realized through QRIS on January 1, 2020, now we can make contactless payments with merchants (Mayanti, 2020). People who want to make transactions can simply save the merchant's QRIS on their cell phone, upload the merchant's QRIS to e-wallet application, and pay for products or services according to nominal. Contactless QRIS is used to support online shopping without face to face, so it will reduce the risk of contracting COVID-19.

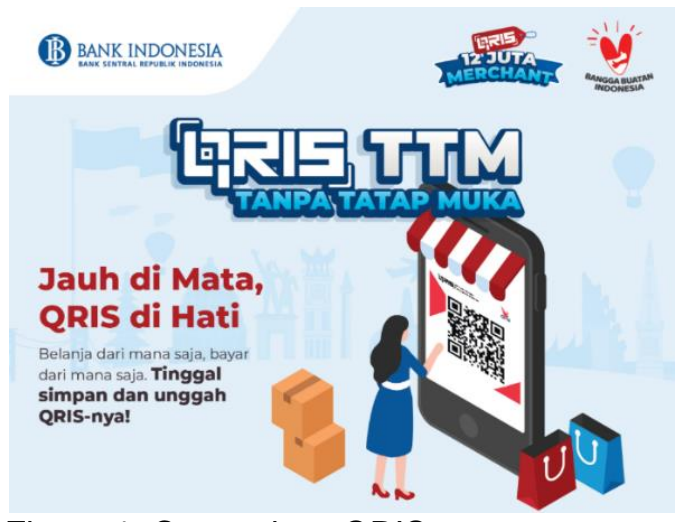

Figure 1. Contactless QRIS

Source: (Indonesia, 2021b)

Advertising is one of the tools in the promotion mix that is most often used by companies. It is well-known and most widely discussed because of its pervasiveness (Belch, Belch, Kerr, Powell, \& Waller, 2020). The truth is, advertising is inseparable from communication to inform and persuade the target audience who heard and saw the advertisement (Tianotak \& Asy'ari, 2019). More specifically, it refers to all forms of marketing communication that disseminate non-personal messages through paid media to reach a wider market (Wono, Deny, Aji, \& Surabaya, 2020).

The attractiveness of advertising is compiled from many elements in it such as images, movements and sounds that affect the human sense of vision and hearing. Creativity is required in creating new ideas in an advertisement, so the advertisement can display extrinsic messages more than just information about the use of products or services (Marta \& Rieuwpassa, 2018). Now, consumers spend more time with online media than conventional media. The characteristic of online media that this media is accessible everywhere with internet connection so information can be conveyed without barrier (Marta, Fernando, \& 
Kurniawati, 2020). The shift in media consumption to digital media has made companies invest more in digital advertising, especially online video (Afriana, Rahayu, \& Agustiningrum, 2017). Believing this, BI positions its products in the eyes of consumers by using the internet and YouTube social media as a platform that plays an important role in framing society's paradigm towards a reality, thus influencing people's attitudes (Harita, Sadono, Sya, Fernando, \& Goswami, 2020).

YouTube occupies the top position in social media with a composition of $90 \%$ nonverbal communication followed by Twitter and Facebook (Wirga, 2016). First launched in 2005, YouTube's name was inspired by a Japanese restaurant in California (Chandra, 2017). In addition, YouTube has more than one billion users with average watch time increasing by $60 \%$ annually (Faiqah Fatty, Nadjib Muh, 2016). YouTube video is one of the fastest ways to connect with customers.

From the many studies on YouTube advertisements, the novelty of this research is the researchers try to explore the object of Contactless QRIS which is related to the pandemic condition that is still happening in Indonesia. Research objects that are usually applied in economics and business research are also brought into the field of communication research to get a different perspective. Researchers hope that this research can enrich the field of advertising in sharpening the function of advertising to consumers which is tailored to the current situation. The research problem is how about the content analysis of advertising "Using Contactless QRIS Practically" on BI YouTube channel. The purpose of this study was to analyze the content of $\mathrm{BI}$ advertising entitled "Using Contactless QRIS Practically".

As a basis for this study, researchers used Means-End Chain (MEC) Theory. This theory that focuses on product development was first introduced by Jonathan Gutman in 1982 (Windharta, Efendy, Christian, \& Damahuri, 2020). This theory explains 3 aspects of attributes, benefits, and values that will influence consumer choice of products or services that are offered by the company. MEC theory also describes the consumer's knowledge of the product, then connects the attributes with the benefits and personal values of the consumer (Arsil, Li, \& Bruwer, 2016). Advertising should contain messages that direct consumers to the end result that the company wants.

Product Knowledge $\longrightarrow$ Self-knowledge

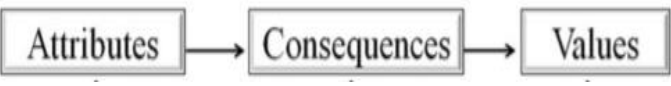

Figure 2. Means-End Chain Model

Source: (Lin \& Tu, 2012)

In the development of a new product, attributes include product or service characteristics that can be seen or measured in real and visible ways. Attributes as the initial foundation of the ultimate goal of the chain. The second aspect is the benefits that are tasked with connecting attributes and values. This benefit can satisfy the consumer's personal values. The theory chain ends at value as the final desired state. This value is closely related to the satisfaction that consumers want to achieve after using the product or service. The relevance of Means-End Chain Theory in this study is that $\mathrm{BI}$ uses aspects of attributes, benefits, and values to develop Contactless QRIS and persuades consumers through advertisements to use Contactless QRIS in the midst of a pandemic.

\section{METHODS}

Researchers use an interpretive paradigm because the researchers want to construct subjective reality from the researchers' point of view (Danu Kristianto \& Marta, 2019). This research is a qualitative research that collects data in the form of words or pictures instead of logical, numerical, or statistical evidence. Qualitative research emphasizes the depth of meaning analysis (U. M. Wahid \& Rizki, 2018). The advantage of qualitative research is that it provides a complete description of the research subject under study of the meaning of phenomena in a particular context (Laurensia, Sitanggang, Marta, Daniar, \& Menayang, 2020). The nature of this research is descriptive research that explains a problem, phenomenon, or event in the field deeply without comparing or connecting with other variables, so it can form a new understanding ( $U$. Wahid \& Puspita, 2017). Descriptive method is designed to obtain meaningful in-depth information (Siahaan, Hendra, \& Matondang, 2019). 
This research is analyzed by using content analysis method. The researcher chooses a content analysis method that describes the aspects and characteristics of the message (Handayani \& Nasionalisme, 2016). Content analysis can be carried out in all forms of communication contained in advertisements, films, newspapers, radio, and other documentation. The documents that are analyzed can be in the form of text or images about facts that have occurred (levansyah \& Sadono, 2018). Researchers will describe the meaning of an advertising creative message through understanding and interpretation (Andrianto, 2018). This study focuses on content analysis of YouTube BI Contactless QRIS advertising messages.

Qualitative data collection techniques are derived from words or actions regarding certain events or contexts that are compiled into information (Siahaan et al., 2019). The document study technique used was taken from journals, websites, news portals, and library data to complement the research. Researchers tested the validity of the data by increasing persistence techniques. With this technique, researchers make detailed and continuous observations to ensure the data obtained is in accordance with the research needs (Sofiyanti, 2020). In this study, the unit of analysis studied was a single case related to the advertisement "Using QRIS Without Face to Face Practically" which was uploaded on the $\mathrm{BI}$ YouTube channel on April 9, 2021 (Indonesia, 2021c).

\section{RESULTS AND DISCUSSION}

The advertisement

"Using

Contactless QRIS Practically" lasted less than 1 minute for only 59 seconds in total. In this advertisement, $\mathrm{BI}$ presents an animation of how to use Contactless QRIS which is easy to be understood and applied. Researchers have ranked 6 important segments ranging from $0.00-0.59$ to be examined as follows:

Segment 1

Complexity of Payment in Pandemic Era Duration: 0.00-0.11

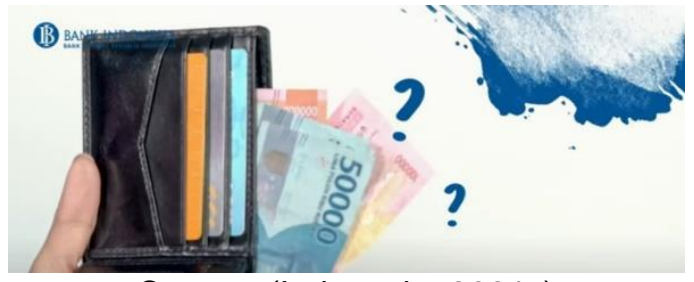

Source: (Indonesia, 2021c)
Starting from the segment of the complexity of payments during a pandemic using cash, Contactless QRIS offers more practical transactions.

Segment 2

Request QR Code from Merchant Duration: 0.17-0.21

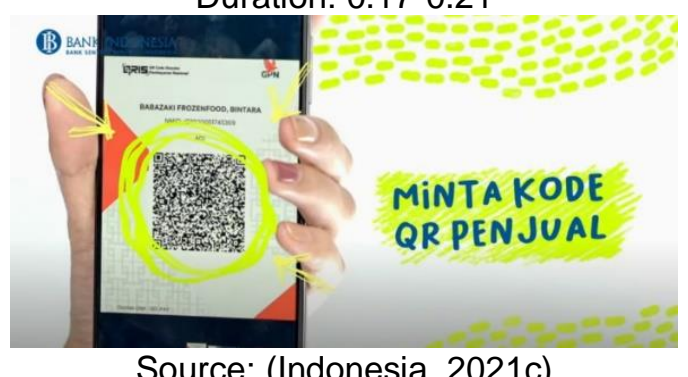

In the second segment, users can request or retrieve a $Q R$ code from the merchant.

Segment 3

Open E-Wallet and Scan QRIS Duration: 0.22-0.29

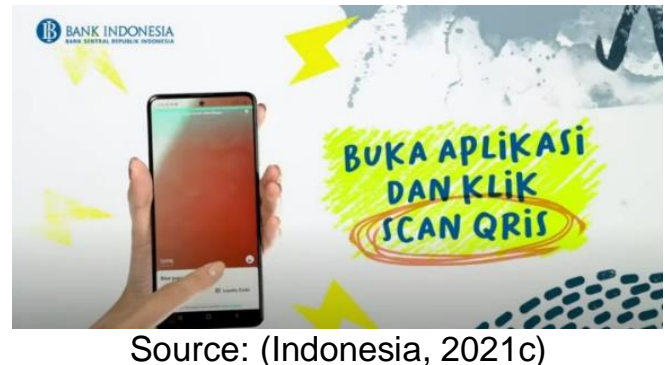

Next, users can immediately open the e-wallet application and press Scan QRIS until the camera appears, then select the small box on the camera.

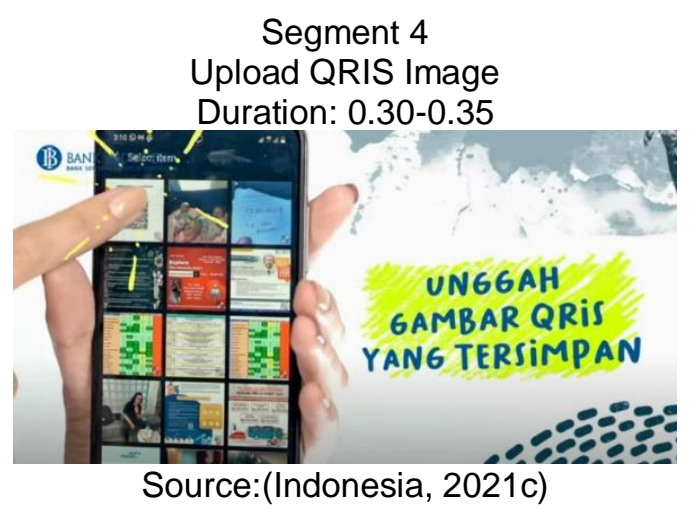

After selecting the small box, user can immediately upload the QRIS image that is already saved on the cell phone. 
Segment 5

Confirm and Check Merchant Name Duration: $0.36-0.41$

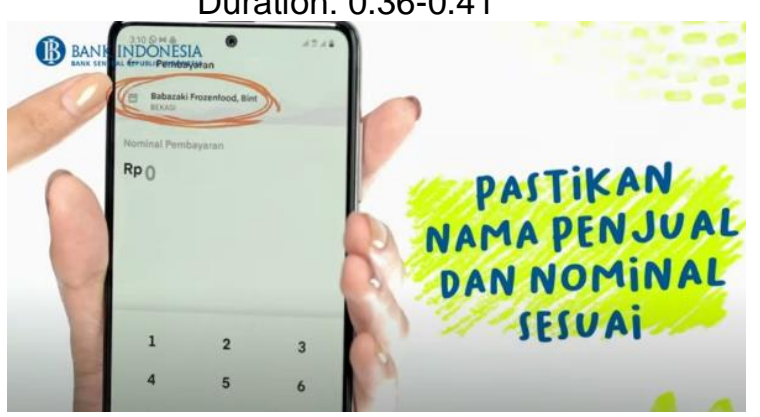

Source: (Indonesia, 2021c)

Users should confirm the merchant name. After being checked, the user can immediately enter the nominal amount according to the transaction.

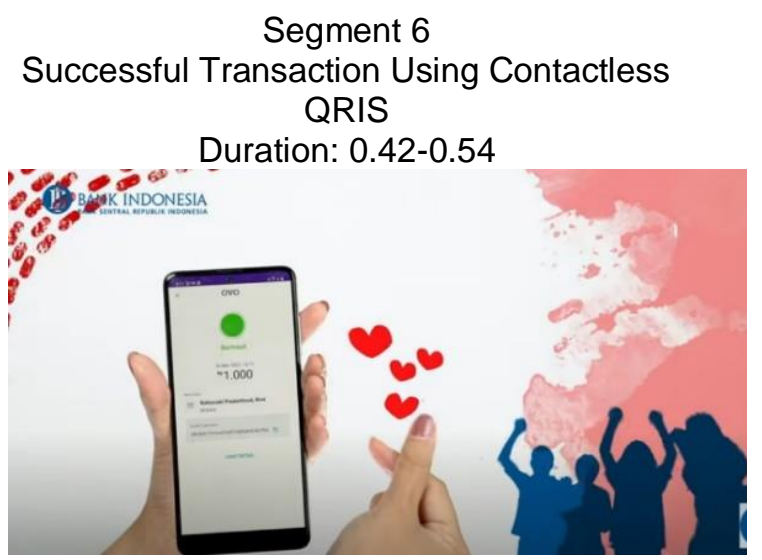

Source: (Indonesia, 2021c)

In seconds, transactions are successfully carried out safely, easily, and calmly. Contactless QRIS can be used to shop and pay anywhere without face to face.

Responding to the condition of the COVID-19 pandemic which is still ongoing today, digital wallets are becoming increasingly sophisticated, replacing physical wallets which are usually full of cash, coins and cards (Aulia, 2020). Comparing to 2019, digital payments are increasingly accepted and are increasingly popular among the public (Gema, Indrawati, Wardhono, \& Nasir, 2020). This digital payment instrument allows users to keep physical distancing which is recommended by World Health Organization (WHO).

Along with technological developments, $\mathrm{BI}$ has also used YouTube as one of advertising platforms. Not even a month since it was launched on YouTube, Contactless QRIS advertisement has reached almost 3,000 views. This advertisement is packaged in a relatively short time with an attractive animation so people can capture the message conveyed quickly. Based on Means-End Chain Theory used by the researchers, $\mathrm{BI}$ has used the attributes, benefits, and values in developing Contactless QRIS. Researchers have mapped the attributes of Contactless QRIS, namely practical, easy, and infection-free. Meanwhile, the benefit when using Contactless QRIS are helping users to implement health protocols and to achieve the values of health and safety.

From the content analysis of advertisement "Using Contactless QRIS Practically" which has been presented, an advertisement does not only have one function but can have double function. Previously, advertising was known to be persuasive in persuading people to buy products or services but advertising can also be used to persuade people to use particular product or service. In addition, advertising can also be educative to change people behaviour. Researchers hope that they can develop further research to analyze the QRIS Transfer, Withdrawal, Deposit (TTS) advertisements that were successfully developed by $\mathrm{BI}$ in June 2020 last year that have not been studied in this study.

\section{CONCLUSIONS RECOMMENDATIONS}

AND

Contactless QRIS advertising has a double function of persuading and educating. The persuasive nature is when $\mathrm{BI}$ encourages users to use Contactless QRIS. Not only that, this advertisement is also educational in educating users about health protocols, especially in transacting in the midst of the COVID-19 pandemic. Research recommendations are divided into academic perspective to deepen the analysis of advertising content in other digital fields, while practical recommendations for $\mathrm{BI}$ to develop advertisements tailored to the latest conditions. In addition, recommendations are also for financial technology companies to provide innovations that can make payment more secure, fast and practical.

\section{REFERENCES}

Afriana, F., Rahayu, A. P., \& Agustiningrum, H. (2017). Hierarki Efek Model Pada Tayangan Iklan Youtube. Jurnal Komunikasi, 2, 140-145.

Aksami, N. M. D., \& Jember, I. M. (2019). Analisis Minat Penggunaan Layanan E-Money Pada Masyarakat Kota Denpasar. E-Jurnal EP Unud, 8(9), 
2439-2470.

Andrianto, N. (2018). Pesan Kreatif Iklan Televisi Ramadan 2017: Analisis Isi Iklan "Bahagianya adalah Bahagiaku." Jurnal Studi Komunikasi (Indonesian Journal of Communications Studies), 2(1), $17-31$. https://doi.org/10.25139/jsk.v2i1.336

Angretnowati, Y., \& Anggraheni, P. (2021). Depoliticization of COVID-19 Pandemic in The Implementation of 2020 Simultaneous Regional Elections. Jurnal Sosial Humaniora Institut Teknologi Sepuluh Nopember, 5521 , $10-24$. https://doi.org/10.2991/assehr.k.21012 5.052

Apriyanti, C., \& Widoyoko, R. D. T. (2021). Persepsi dan Aksi Masyarakat Pedesaan di Masa Pandemi. Jurnal IImu Sosial Dan Humaniora, 10(1), 5069.

Arsil, P., Li, E., \& Bruwer, J. (2016). Using Means-End Chain Analysis to Reveal Consumers' Motivation for Buying Local Foods: An Exploratory Study. Gadjah Mada International Journal of Business, 18(3), 285-300. https://doi.org/10.22146/gamaijb.6061

Aulia, S. (2020). Pola Perilaku Konsumen Digital Dalam Memanfaatkan Aplikasi Dompet Digital. Jurnal Komunikasi, 12(2), 311. https://doi.org/10.24912/jk.v12i2.9829

Belch, G. E., Belch, M. B., Kerr, G., Powell, I., \& Waller, D. (2020). Advertising: An Integrated Marketing Communication Perspective 4e. In Advertising and Promotion. An Integrated Marketing Communication Perspective. McGrawHill Education (Australia) Pty Ltd.

Chandra, E. (2017). YouTube Citra Media Informasi Interaktif atau Media Penyampaian Aspirasi Pribadi. Jurnal Muara Ilmu Sosial, Humaniora, Dan Seni Universitas Tarumanagara, 1(2), 406-417. Retrieved from https://journal.untar.ac.id

Danu Kristianto, B. R., \& Marta, R. F. (2019). Simplifikasi Ritual Harai Dan Dimensi Kultural Hofstede Dalam Iklan Forte Versi Sumo. Bricolage: Jurnal Magister IImu Komunikasi, 5(01), 091. https://doi.org/10.30813/bricolage.v5i0 1.1744

Faiqah Fatty, Nadjib Muh, A. A. S. (2016). YouTube Sebagai Sarana Komunikasi Bagi Komunitas Makassarvidgram. Jurnal Komunikasi Kareba, 16(1), 28-
42.

https://doi.org/10.1080/14639947.201 5.1006801

Falah, M. N., \& Puspaningrum, A. (2020). Pengaruh Persepsi Kemudahan, Persepsi Kepercayaan, dan Persepsi Risiko Terhadap Minat Menggunakan Kembali Shopee Pay di Kota Malang Saat Pandemi COVID-19. Jurnal IImiah Mahasiswa Fakultas Ekonomi Dan Bisnis Universitas Brawijaya, 118.

Gema, C., Indrawati, Y., Wardhono, A., \& Nasir, M. A. (2020). Dampak Perkembangan Uang Elektronik terhadap Efektivitas Kebijakan Moneter di Indonesia. Jurnal Ekonomi Indonesia, 9(3), 265-277.

Handayani, L. R., \& Nasionalisme, P. (2016). Analisis Isi Pesan Nasionalisme Pada Iklan Coca-Cola Reason To Believe Indonesia Tahun 2012. IImu Komunikasi, 4, 101-114.

Harita, F. M., Sadono, T. P., Sya, M., Fernando, J., \& Goswami, J. K. (2020). Traveloka as The Ultimate Workplace for Millennial Graduates in Information and Technology. Aspiration, 1(2), 163181.

levansyah, I., \& Sadono, T. P. (2018). Personal Branding Dalam Komunikasi Selebritis (Studi Kasus Personal Branding Alumni Abang None Jakarta Di Media Sosial "Instagram"). Bricolage: Jurnal Magister IImu Komunikasi, 4(02), 149. https://doi.org/10.30813/bricolage.v4i0 2.1658

Indonesia, B. (2021a). BI dan Industri Targetkan Perluasan QRIS Capai 12 Juta Merchant di 2021. Retrieved from https://www.bi.go.id/id/publikasi/ruangmedia/newsrelease/Pages/sp_233721.aspx

Indonesia, B. (2021b). Cara menggunakan QRIS TTM (Tanpa Tatap Muka). Retrieved from https://bicara.bi.go.id/knowledgebase/ article/KA-01062/en-us

Indonesia, B. (2021c). Praktis Pakai QRIS TTM. Retrieved from https://www.youtube.com/watch?v=Q KLsIwIACag

Komite Penanganan COVID-19 Dan Pemulihan Ekonomi Nasional. (2021). Situasi COVID-19 Di Indonesia. Retrieved from https://covid19.go.id/berita/datavaksinasi-covid-19-update-6-mei-2021 
Laurensia, B., Sitanggang, H. J., Marta, R. F., Daniar, A., \& Menayang, A. P. (2020). Integrasi Orkestrasi Pemasaran dengan Filosofi Dwi Sapta pada Kasus Vaseline Healing Project. Jurnal Komunikasi Nusantara, 2(1), 28-41. https://doi.org/10.33366/jkn.v2i1.38

Lin, Y. L., \& Tu, Y. Z. (2012). The Values of College Students in Business Simulation Game A Means-End Chain Approach. Elsevier, 58(4), 1160-1170. https://doi.org/10.1016/j.compedu.201 1.12 .005

Marta, R. F., Fernando, J., \& Kurniawati, L. S. M. W. (2020). Tinjauan Peran Komunikasi Keluarga Pada Kinerja Public Relations Melalui Konten Laman Resmi Media Daring Kpppa. Jurnal Komunikasi Pembangunan, 18(01), 30-42. https://doi.org/10.46937/18202028620

Marta, R. F., \& Rieuwpassa, J. S. (2018). Identifikasi Nilai Kemajemukan Indonesia Sebagai Identitas Bangsa dalam Iklan Mixagrip Versi Keragaman Budaya. Jurnal Kajian Komunikasi, 6(1), 37. https://doi.org/10.24198/jkk.v6i1.1541 6

Mayanti, R. (2020). Faktor-Faktor Yang Mempengaruhi Penerimaan User Terhadap Penerapan Quick Response Indonesia Standard Sebagai Teknologi Pembayaran Pada Dompet Digital. Jurnal Ilmiah Ekonomi Bisnis, 25(2), 123-135.

https://doi.org/10.35760/eb.2020.v25i2 .2413

Perbawa, I. K. L. (2021). Kebijakan Pemerintah Indonesia Dalam Menanggulangi Covid-19 Berdasarkan. Jurnal IImu Sosial Dan Humaniora, 10(1), 197-205.

Saputri, O. B. (2020). Preferensi Konsumen Dalam Menggunakan Quick Response Code Indonesia Standard (QRIS) Sebagai Alat Pembayaran Digital. Journals of Economics and Business Mulawarman, 17(2), 237-247.

Sari, M. K. (2021). The Impacts of COVID19 Pandemy on Technology Literacy Usage on Students Learning Experience. Jurnal Sosial Humaniora Institut Teknologi Sepuluh Nopember, 43-51.

Setiawan, I. W. A., \& Mahyuni, L. P. (2020). QRIS Di Mata UMKM: Eksplorasi Persepsi Dan Intensi UMKM
Menggunakan QRIS. E-Jurnal Ekonomi Dan Bisnis Universitas Udayana, 10, 921-946.

Siahaan, W. C., Hendra, Y., \& Matondang, A. (2019). Strategi Komunikasi Pemasaran Perusahan Terbatas OPPO Indonesia dalam Meningkatkan Citra Smartphone OPPO. Jurnal Perspektif, 6(1), 8-12.

Sofiyanti, F. (2020). Pembelajaran Online Pada Masa Pandemi COVID-19 Di Kelompok Bermain (KB) Mawar Desa Sumberkolak Situbondo Tahun 2020. Jurnal IKA PGSD (Ikatan Alumni PGSD) UNARS, 8(1), 232. https://doi.org/10.36841/pgsdunars.v8i 1.624

Tianotak, J., \& Asy'ari, N. A. S. (2019). Makna Tagline 'Menjadi Yang Terbaik' Iklan Telkomsel Versi Pilot Papua Riko Kabak. Bricolage : Jurnal Magister IImu Komunikasi, 5(01), 049. https://doi.org/10.30813/bricolage.v5i0 1.1742

Wahid, U. M., \& Rizki, M. F. (2018). Upaya Komunikasi Pemasaran Terpadu Televisi Lokal Melalui Budaya Lokal. Jurnal Kajian Komunikasi. https://doi.org/10.24198/jkk.v6i2.1582 1

Wahid, U., \& Puspita, A. E. (2017). Upaya Peningkatkan Brand Awareness PT. Go-Jek Indonesia Melalui Aktivitas Marketing Public Relations. Jurnal Komunikasi, 9(1), 31. https://doi.org/10.24912/jk.v9i1.265

WHO. (2020). Anjuran Mengenai Penggunaan Masker Dalam Konteks COVID-19. World Health Organization, (April), 1-17.

Widyastuti, D. A. R., Nuswantoro, R., \& Sidhi, T. A. P. (2016). Literasi Digital pada Perempuan Pelaku Usaha Produktif di Daerah Istimewa Yogyakarta. Jurnal ASPIKOM, 3(1), 1. https://doi.org/10.24329/aspikom.v3i1. 95

Windharta, A., Efendy, A. C., Christian, D., \& Damahuri, M. R. (2020). Pengembangan Produk Baru dengan Menggunakan Means-End Chain Theory: Kasus Water+. Indonesian Business Review, 2(2), 315-354. https://doi.org/10.21632/ibr.2.2.315354

Wirga, E. W. (2016). Analisis Konten Pada Media Sosial Youtube untuk Mendukung Strategi Kampanye Politik. Jurnal IImiah Informatika Dan 
Evelyn Kristanti, Rustono Farady Marta | Persuasive and Educative Advertising Content of Quick Response Code Indonesian Standard in Pandemic Era

Komputer, 21(100), 14-26. Retrieved

from

https://ejournal.gunadarma.ac.id/index .php/infokom/article/view/1716

Wono, H. Y., Deny, I., Aji, K., \& Surabaya,

U. C. (2020). Preferensi Komunikasi

Pemasaran Terpadu Perguruan Tinggi

Di Surabaya Pada Era Posmoderen.

Bricolage : Jurnal Magister IImu

Komunikasi, 6(2), 171-185. 